\title{
The one-step pyrolysis process of rattan-based silicon carbide multiphase ceramics prepared by sol-gel method
}

\author{
Shijie Li ${ }^{1}$, Heshuai Cui ${ }^{1}$, Qianli Ma ${ }^{1}$, Xing'e Liu' ${ }^{1}$ Youhong Wang ${ }^{2}$, Lili Shang ${ }^{1 *}$ [D and Yu Zheng ${ }^{3^{*}}$
}

\begin{abstract}
The sol-gel method was used to prepare rattan-based silicon carbide (R-SiC) composite ceramics under different pyrolysis parameters through adjustment of the temperature and retention time of the one-step pyrolysis process. The crystalline phases, microscopic morphology, element distribution and specific surface area of the silicon carbide $(\mathrm{SiC})$ were characterized by X-ray diffraction (XRD), Fourier transform-infrared spectroscopy (FT-IR), X-ray fluorescence spectrometer (XRF), field-emission scanning electron microscope (FESEM), transmission electron microscopy (TEM), energy dispersive $\mathrm{X}$-ray analysis (EDX), and $\mathrm{N}_{2}$ physisorption. The results showed that the $\mathrm{R}-\mathrm{SiC}$ prepared at different pyrolysis parameters was able to retain the porous structure of pristine rattan stem. The R-SiC prepared at $1500{ }^{\circ} \mathrm{C}$ for 120 min possessed the lowest density $\left(0.25 \mathrm{~g} / \mathrm{cm}^{3}\right)$, the largest specific surface area $\left(43.38 \mathrm{~m}^{2} / \mathrm{g}\right)$ and the highest $\mathrm{SiC}$ yield (44.24\%). The SiC whisker was the major SiC morphology on the cross section of the R-SiC. Furthermore, the pyrolysis parameters were optimized with the $\mathrm{SiC}$ preparation process reaction mechanism, and material transformation methods were also discussed. This one-step pyrolysis process simplified the preparation of biogenic SiC ceramics and thus provided a potential route for the value-added utilization of rattan.
\end{abstract}

Keywords: Rattan, SiC ceramics, Sol-gel method, Pyrolysis process

\section{Introduction}

Silicon carbide $(\mathrm{SiC})$ ceramics is a high-performing structural ceramic material. It has extremely high hardness and mechanical strength, great thermal stability, superior electrical properties and chemical inertness [1]. It is widely used in many industries such as automobiles, aerospace, electronic machinery, and nuclear magnetic field, and potentially has wide applications [2]. SiC ceramics is generally synthesized through the chemical vapor deposition (CVD) of silane compounds [3, 4], precursor infiltration pyrolysis (PIP) of organosilicon polymers [5-7], direct carbonization of elemental silicon $(\mathrm{Si})$

\footnotetext{
*Correspondence: shangll_1130@126.com; zhengyu1210@126.com

1 Key Lab of Bamboo and Rattan Science and Technology, International Centre for Bamboo and Rattan, Beijing 100102, China

${ }^{3}$ Beijing Research Institute of Synthetic Crystals Co. Ltd, Beijing 100018, China

Full list of author information is available at the end of the article
}

and carbothermic of silicon dioxide $\left(\mathrm{SiO}_{2}\right)$ reduction. Of them, CVD can produce high-purity $\mathrm{SiC}$ ceramics, but expensive raw materials, complex reaction equipment and the harmfulness precursors restrict its large-scale industrial production. The molecular structure of the PIP precursor is designable desirable. Although its molding process is simple, the reaction temperature is low, and it has a certain ceramic yield, its precursor releases a large amount of gas during the thermal cracking process, which easily leads to large volume shrinkage, deformation, cracking and collapse of the ceramic matrix $[8,9]$. The elemental silicon direct carbonization and the $\mathrm{SiO}_{2}$ carbothermic reaction are also considered to be ideal $\mathrm{SiC}$ preparation methods thanks to their inexpensive raw materials, simple processes and equipment and high production efficiency. However, they have some shortcomings. Their maximum reaction temperature can reach $2700{ }^{\circ} \mathrm{C}$ due to the lack of effective contact between the
Springer Open (c) The Author(s) 2021. Open Access This article is licensed under a Creative Commons Attribution 4.0 International License, which permits use, sharing, adaptation, distribution and reproduction in any medium or format, as long as you give appropriate credit to the original author(s) and the source, provide a link to the Creative Commons licence, and indicate if changes were made. The images or other third party material in this article are included in the article's Creative Commons licence, unless indicated otherwise in a credit line to the material. If material is not included in the article's Creative Commons licence and your intended use is not permitted by statutory regulation or exceeds the permitted use, you will need to obtain permission directly from the copyright holder. To view a copy of this licence, visit http://creativecommons.org/licenses/by/4.0/. 
reactants. It may result in the low probability of intermolecular collisions. As a result, higher temperatures are needed. In order to effectively overcome this problem, more suitable raw materials are used to increase the contact area between the reactants to reduce the reaction temperature [10,11].

The $\mathrm{SiC}$ material made from biomass through organicinorganic transformation is a new environmentally friendly material with unique biological structure and ceramic properties [12]. So far, researches on $\mathrm{SiC}$ composite ceramics are limited mainly to wood, crops and their products and wastes as raw bio-materials. Rattan is also a renewable bio-material after bamboo and wood. This raw material is composed mainly of parenchyma cells, fibers and vessels $[13,14]$. Due to the absence of secondary growth, the rattan stems have a complete primary form in nature, and do not produce phloem outwardly and xylem inwardly [15]. Rattan usually has three different macroporous pore diameters of $300 \mu \mathrm{m}$, 6-20 $\mu \mathrm{m}$ and 1-3 $\mu \mathrm{m}$ [16]. Therefore, using rattan as a raw material for the making of $\mathrm{SiC}$ multiphase ceramics makes a larger amount of external silicon sources easier to enter the pores of the rattan, thus increases the contact area between the reactants. The chemical composition of rattan, similar to that of wood, is composed mainly of $\alpha$-cellulose (42-53\%), hemicellulose (19-27\%) and lignin (20-40\%) [17]. Thanks to its high carbon content, rattan provides sufficient carbon source enabling the $\mathrm{Si}$ source to enter into the material. Moreover, rattan has a short growth cycle, low density, low transverse stem shrinkage, excellent toughness, easy processing, and high carbon content $[18,19]$. These characteristics make rattan an ideal raw material for biomass-based $\mathrm{SiC}$ composite ceramics. Using rattan as a raw material for the manufacturing of $\mathrm{SiC}$ composite ceramics make external silicon sources easier to get into the rattan pores, thus increases the contact area between the reactants and reduce the reaction temperature. This serves as a value-added application for rattan.

In our previous study, rattan-based silicon carbide $(\mathrm{R}-\mathrm{SiC})$ ceramics was prepared using $\mathrm{SiO}_{2}$ sol and liquid melt-Si method. Our study found that the $\mathrm{SiO}_{2}$ sols from rattan were more appropriate than that from wood for the preparation of $\mathrm{SiC}$ with higher yield and purity from rattan [20]. The present study utilized rattan and $\mathrm{SiO}_{2}$ sol as raw materials for the manufacturing of $\mathrm{SiC}$ composite ceramics through the sol-gel method under one-step pyrolysis. The $\mathrm{SiO}_{2}$ sol was prepared with ethyl orthosilicate, absolute ethanol, and deionized water as raw materials, using hydrochloric acid as a catalyst. A vacuum-pressure impregnation method was used to impregnate the rattan into the sol to obtain a $\mathrm{SiO}_{2}$ solgel/rattan mixture, which is pyrolyzed to generate $\mathrm{R}-\mathrm{SiC}$.
The $\mathrm{R}-\mathrm{SiC}$ materials are stable in nature and have good resistance in many aspects. Therefore, these $\mathrm{R}-\mathrm{SiC}$ materials can be used in the fields of electricity, adsorption, new materials, fabrication and machinery [21, 22]. The morphology, yield and phase structure of the synthesized $\mathrm{R}-\mathrm{SiC}$ were investigated. This one-step pyrolysis process simplified the preparation of biogenic $\mathrm{SiC}$ ceramics and thus may provide a value-added end-use for rattan.

\section{Materials and methods \\ Materials}

Canes of Daemonorops jenkinsiana (Griffith) Martius were collected from Nanmeiling Forest Park in Baisha county, Hainan province, China. The rattan diameter without sheath ranges from about $1.0 \mathrm{~cm}$ to $2.5 \mathrm{~cm}$. Ethyl orthosilicate (TEOS, analytical reagent) was purchased from Sino pharmaceutical Reagent Co., LTD. Anhydrous ethanol (EtOH, analytical reagent) was purchased from Tianjin Damao Chemical Reagent Factory. Hydrochloric acid was purchased from the National Quality Inspection Center for Chemical Reagents. The standard titration solution $(1 \mathrm{~mol} / \mathrm{L})$ and deionized water was made in the lab.

\section{Experimental method \\ Raw material pretreatment}

Samples preparation Three mature air-dried canes without obvious defects were selected. A 5-mm-thick piece was sampled at the middle of each canes. These samples were kept in the dry place for use. The content of $\mathrm{SiO}_{2}$ in the original rattan is $0.11 \%$.

Silicon sol preparation Ethylene-silicate, anhydrous ethanol and deionized water were mixed in accordance with the molar ratio of 1:4:6. The $\mathrm{pH}$ value of the solution was adjusted to 2.5 by applying hydrochloric acid, and $\mathrm{SiO}_{2}$ sol was fully stirred until it became colorless and transparent. When the temperature was cooled down to room temperature, the sol was stored in refrigerator [23].

Impregnation The $\mathrm{SiO}_{2}$ sol was ultrasonically treated for $10 \mathrm{~min}$. Then, it was impregnated with rattan piece using the vacuum-pressure impregnation method. After drying, a gel/rattan piece mixture with a mass ratio of 7:39 was obtained (see Fig. 1).

\section{Preparation of the SiC composite ceramics by one-step pyrolysis}

$10.00 \mathrm{~g}$ of the gel/rattan piece mixture was put into a crucible, covered with a lid and placed in a vacuum high-temperature tube furnace. The mixture was held at the desired temperature $\left(1300,1400,1500{ }^{\circ} \mathrm{C}\right)$ for 120 min under the argon atmosphere. The temperature 


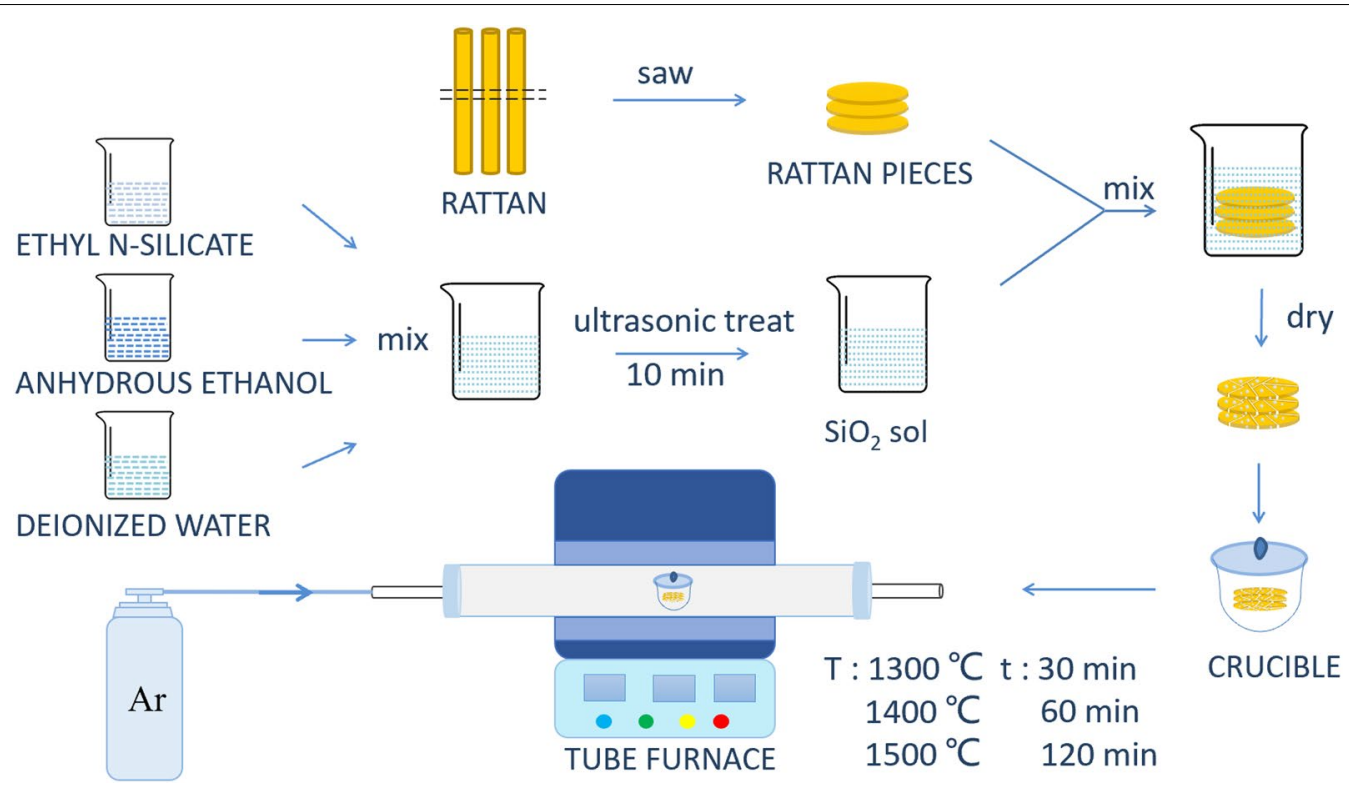

Fig. 1 Schematic diagram of rattan-based SiC (R-SiC) preparation process

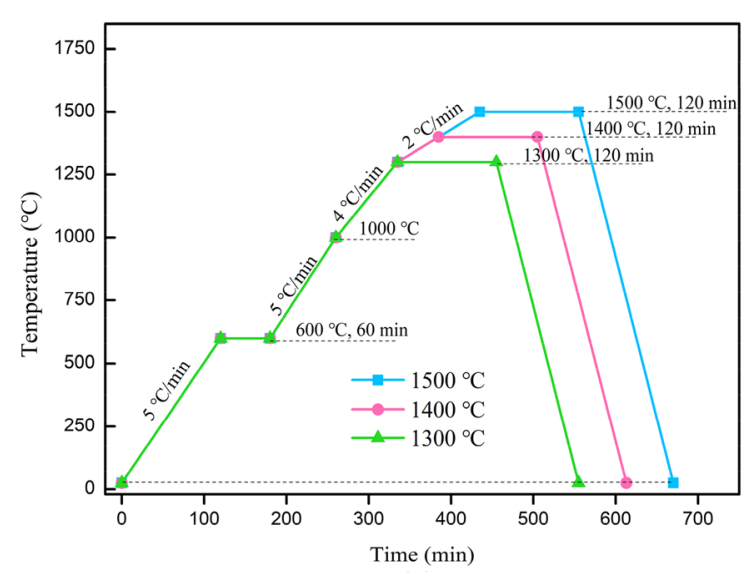

(a)

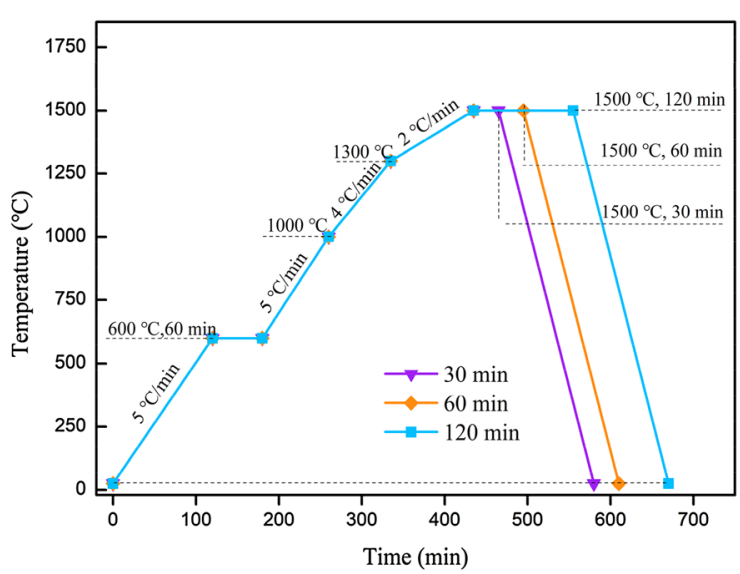

(b)

Fig. 2 The pyrolysis curve for the preparation of $\mathrm{R}-\mathrm{SiC}$ at $\mathbf{a}$ different temperatures; $\mathbf{b}$ different retention times

curve of the ceramics is shown in Fig. 2a. The SiC composite ceramics prepared at three pyrolysis temperatures are marked as $\mathrm{R}-\mathrm{SiC}_{\mathrm{T} 1300 \mathrm{t} 120}, \mathrm{R}-\mathrm{SiC}_{\mathrm{T} 1400 t 120}$ and $\mathrm{R}-\mathrm{SiC}_{\mathrm{T} 1500 \mathrm{t} 120}$. The $\mathrm{R}-\mathrm{SiC}$ stands for the $\mathrm{SiC}$ composite ceramics prepared from rattan, and the others represent the composites prepared at pyrolysis temperatures of 1300,1400 and $1500{ }^{\circ} \mathrm{C}$, respectively. All the experiments were conducted in triplicate.

\section{SiC composite ceramics at different retention times}

$10.00 \mathrm{~g}$ of the gel/rattan piece mixture was put into a crucible, covered with a lid and transferred to a vacuum high-temperature tube furnace. Under the argon atmosphere, the mixture was maintained at $1500{ }^{\circ} \mathrm{C}$ for 30, 60, and $120 \mathrm{~min}$, respectively. The pyrolysis curve of the ceramics is shown in Fig. 2b. The SiC composite ceramics prepared at three retention times are marked as $\mathrm{R}-\mathrm{SiC}_{\mathrm{T} 1500 t 30}, \mathrm{R}-\mathrm{SiC}_{\mathrm{T} 1500 t 60}$ and $\mathrm{R}-\mathrm{SiC}_{\mathrm{T} 1500 \mathrm{t} 120}$. The $\mathrm{R}-\mathrm{SiC}$ stands for $\mathrm{SiC}$ composite ceramics prepared from rattan, and in others " $\mathrm{T}$ " refers to the temperature with and " $t$ " is refers to the duration of retention time (30, $60,120 \mathrm{~min})$. All the experiments were conducted in triplicate. 


\section{Characterization}

The mass changes of the samples during the transformation of the rattan/silica material into the $\mathrm{SiC}$ ceramic were measured to $0.0001 \mathrm{~g}$ using an analytical balance (PL303-IC, Mettler-Toledo, Switzerland). The phase composition and crystallographic structure of the $\mathrm{SiC}$ samples were determined by X-ray diffraction (XRD, Bruker AV300, Philips, Holland) with a nickel filtered $\mathrm{Cu}$ Ka radiation over the $2 \mathrm{~h}$ range of 5-90 at a scanning speed of $4 \% \mathrm{~min}$. In addition, the elemental analyses of the $\mathrm{SiC}$ samples were conducted using the X-ray fluorescence (XRF, Shimadzu1800, Shimadzu, Japan). The chemical bonds and functional groups of the $\mathrm{SiC}$ samples were investigated using a Fourier transform-infrared spectroscopy (FT-IR, Nexus670, Nicolet, USA) at ambient conditions. The morphology and microstructure of the $\mathrm{SiC}$ samples were examined under a field-emission scanning electron microscope (FESEM, XL-30, FEI, USA). An energy dispersive X-ray analysis (EDX, FEG132-10, FEI, USA) equipped with FESEM was also carried out to determinate the element composition of the $\mathrm{SiC}$ samples corresponding to the FESEM images. High-resolution transmission electron microscope (TEM, JEM-2100F, JEOL, Japan) was used to study the interface binding between the $\mathrm{SiC}$ and carbon. The specific surface area of the $\mathrm{SiC}$ samples was obtained by $\mathrm{N}_{2}$ physisorption instrument (ASAP2020, Micromeritics, USA).

\section{Results and discussion}

\section{Mass residue and density analysis}

The mass residue and density of the $\mathrm{SiC}$ composite ceramics formed by the gel/rattan piece mixtures at different pyrolysis temperatures and the retention times showed significant differences, as shown in Table 1. The samples exhibited a trend of $\mathrm{R}-$ $\mathrm{SiC}_{\mathrm{T} 1300 \mathrm{t} 120}>\mathrm{R}-\mathrm{SiC}_{\mathrm{T} 1400 \mathrm{t} 120}>\mathrm{R}-\mathrm{SiC}_{\mathrm{T} 1500 \mathrm{t} 120}$ and $\mathrm{R}-$ $\mathrm{SiC}_{\mathrm{T} 1500 \mathrm{t} 30}>\mathrm{R}-\mathrm{SiC}_{\mathrm{T} 1500 \mathrm{t} 60}>\mathrm{R}-\mathrm{SiC}_{\mathrm{T} 1500 \mathrm{t} 120}$. The mass residue of the $\mathrm{R}-\mathrm{SiC}$ samples decreases with increasing temperature and retention time. For example, the mass residue of the sample $\mathrm{R}-\mathrm{SiC}_{\mathrm{T} 1500 \mathrm{t} 120}$ is only $68.91 \%$ of the $\mathrm{R}-\mathrm{SiC}_{\mathrm{T} 1300 \mathrm{t} 120}$ and $82.73 \%$ of the $\mathrm{R}-\mathrm{SiC}_{\mathrm{T} 1500 \mathrm{t} 30}$. Besides, the density of the $\mathrm{R}-\mathrm{SiC}$ samples shows a decreasing trend with increasing pyrolysis reaction temperature and duration of the retention time.

\section{Analysis of specific surface area}

The specific surface areas of $\mathrm{R}-\mathrm{SiC}$ are shown in Table 1. The specific surface areas of the samples goes up with increasing pyrolysis temperature and retention time, as the $\mathrm{SiO}_{2}$ sol is coated on the surface of the pore structure or accumulated in the pores after passing through the gel before pyrolysis. With the progress of the carbothermal reduction reaction, the $\mathrm{SiO}_{2}$ gel is gradually consumed by reduction and deoxidization so that the pore structure is gradually exposed. As the temperature rises and the retention time prolongs, the progress of the carbothermal reduction reaction and the formation of $\mathrm{SiC}$ will be promoted. This results in more $\mathrm{SiO}_{2}$ gel consumption, fewer pores covered by residual $\mathrm{SiO}_{2}$ gel, and an increase in specific surface area.

\section{Phase analysis}

The XRD was used to identify the phase composition of the obtained $\mathrm{R}-\mathrm{SiC}$ samples prepared at different conditions. As shown in Fig. 3a, the XRD curve at different temperatures of $1300-1500{ }^{\circ} \mathrm{C}$ exhibits two typical peaks at $2 \theta=35.8^{\circ}$ and $22.0^{\circ}$. The peak at $2 \theta=35.8^{\circ}$ corresponds to (111) crystal planes of $\beta$-SiC according to the joint committee on powder diffraction standards (JCPDS) \#29-1129 [22]. This indicates that the gel/rattan piece mixture can be transformed into the $\mathrm{SiC}$ complex ceramics at all designed temperatures. The intensity of the peaks is $\mathrm{R}-\mathrm{SiC}_{\mathrm{T} 1300 t 120}$ (848 a.u.) $<\mathrm{R}-\mathrm{SiC}_{\mathrm{T} 1400 \mathrm{t} 120}(880$ a.u.) $<\mathrm{R}-\mathrm{SiC}_{\mathrm{T} 1500 t 120}$ (1292 a.u.). This indicates that the intensity of the peaks rises with increasing temperature. The diffraction peaks with $2 \theta$ values of $22^{\circ}$ corresponds to the 101 crystal planes of quartzite (JCPDS Card No. 39-1425), showing the existence of crystalline $\mathrm{SiO}_{2}$ in all the samples. In addition, two weak peaks representing quartzite were found at $28.5^{\circ}$ and $31.5^{\circ}$ in $\mathrm{R}-\mathrm{SiC}_{\mathrm{T} 1300 \mathrm{t} 120}$, corresponding to (111) and (102) crystal planes of

Table 1 The mass residue, density and specific surface area of the R-SiC prepared at different pyrolysis conditions

\begin{tabular}{llllll}
\hline Sample & $\begin{array}{l}\text { Temperature } \\
\left({ }^{\circ} \mathrm{C}\right)\end{array}$ & $\begin{array}{l}\text { Time } \\
(\mathbf{m i n})\end{array}$ & Mass residue (\%) & Density $\left(\mathbf{g} / \mathbf{c m}^{\mathbf{3})}\right.$ & $\begin{array}{l}\text { Specific } \\
\text { surface area } \\
\left(\mathbf{m}^{2} / \mathbf{g}\right)\end{array}$ \\
\hline 1 & & 120 & $41.08 \pm 0.62$ & 0.38 & $30.75 \pm 0.31$ \\
2 & 1300 & 120 & $31.59 \pm 0.79$ & 0.27 & $40.39 \pm 0.50$ \\
3 & 1400 & 120 & $28.31 \pm 0.28$ & 0.25 & $43.48 \pm 0.87$ \\
4 & 1500 & 60 & $30.77 \pm 0.37$ & 0.34 & $21.23 \pm 0.32$ \\
5 & 1500 & 30 & $34.22 \pm 0.60$ & 0.36 & $7.47 \pm 0.18$ \\
\hline
\end{tabular}




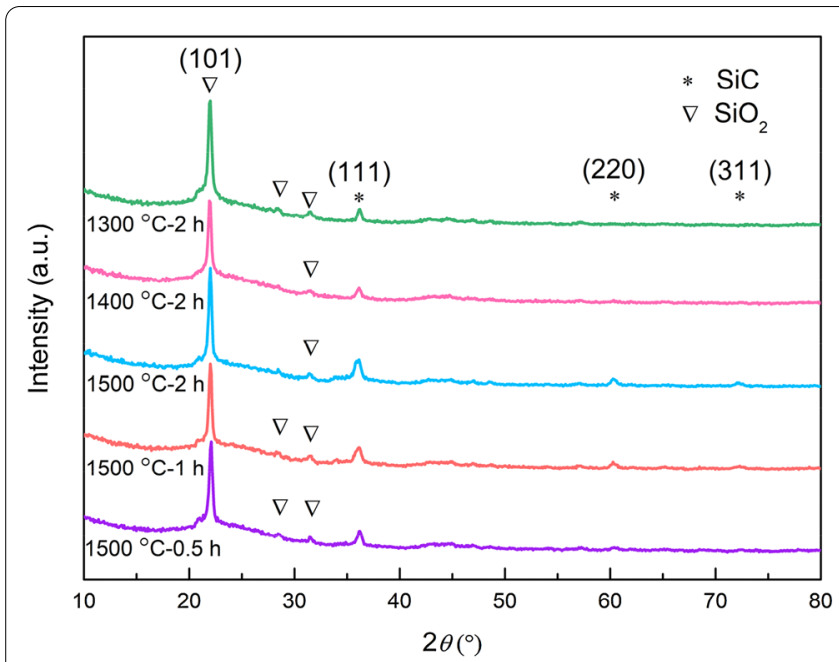

(a)

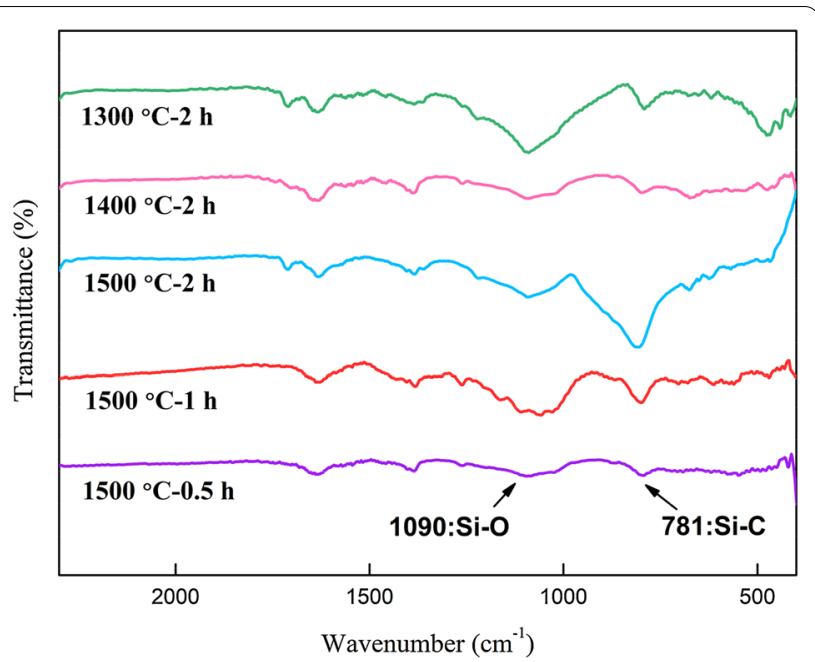

(b)

Fig. 3 a XRD patterns of R-SiC prepared at different temperatures and retention times; $\mathbf{b}$ FT-IR spectra of R-SiC prepared at different temperatures and retention times

quartzite, respectively. As the temperature goes up, the diffraction peak of the crystal planes (111) of $\mathrm{SiO}_{2}$ is not found at $2 \theta=28.5^{\circ}$ in $\mathrm{R}-\mathrm{SiC}_{\mathrm{T} 1400 \mathrm{t} 120}$ and $\mathrm{R}-\mathrm{SiC}_{\mathrm{T} 1500 \mathrm{t} 120 \text {. }}$ This indicates that temperature considerably affects the $\mathrm{SiO}_{2}$ thermal reduction reaction. In the $\mathrm{R}-\mathrm{SiC}_{\mathrm{T} 1500 \mathrm{t} 120}$, there are two peaks at $60.1^{\circ}$ and $71.9^{\circ}$, corresponding to (220) and (311) crystal planes of the $\beta$-SiC, respectively. However, there are no two peaks at the same positions of the $\mathrm{R}-\mathrm{SiC}_{\mathrm{T} 1300 \mathrm{t} 120}$ and the $\mathrm{R}-\mathrm{SiC}_{\mathrm{T} 1400 \mathrm{t} 120}$. In combination with the diffraction peak intensity change of the $\beta$-SiC (111) crystal plane at $2 \theta=35.8^{\circ}$, it appears that there are more $\mathrm{SiC}$ in the $\mathrm{R}-\mathrm{SiC}_{\mathrm{T} 1500 t 120}$ sample. Gu et al. [24] reported that the low yield of the $\mathrm{SiC}$ was due to the low pyrolysis temperature, and more $\mathrm{Si}$ crystals were produced with increasing temperature. Similarly, Kuang et al. [25] also found that there was some unreacted $\mathrm{SiO}_{2}$ at low temperature. When the temperature rises, the peak signal of the $\mathrm{SiO}_{2}$ decreases, whereas the peak signal of the $\mathrm{SiC}$ increases. Obviously, the pyrolysis temperature affects the yield and purity of the $\mathrm{SiC}$ in the $\mathrm{R}-\mathrm{SiC}$ samples.

The XRD of the $\mathrm{R}-\mathrm{SiC}_{\mathrm{T} 1500 t 30}$, the $\mathrm{R}-\mathrm{SiC}_{\mathrm{T} 1500 \mathrm{t} 60}$ and the $\mathrm{R}-\mathrm{SiC}_{\mathrm{T} 1500 t 120}$ under the temperature of $1500^{\circ} \mathrm{C}$ is shown in Fig. 3a. Figure $3 \mathrm{~b}$ shows that there are three diffraction peaks in the $\mathrm{R}-\mathrm{SiC}_{\mathrm{T} 1500 \mathrm{t} 120}$ at $2 \theta$ value of $35.8^{\circ}, 60.1^{\circ}$ and $71.9^{\circ}$, corresponding to (111), (220) and (311) crystal planes of the $\beta-\mathrm{SiC}$. The (111) crystal plane of the $\beta$-SiC is also observed in the $\mathrm{R}-\mathrm{SiC}_{\mathrm{T} 1500 t 30}$ and the $\mathrm{R}-\mathrm{SiC}_{\mathrm{T} 1500 \mathrm{t} 60}$, and the peak intensity is $\mathrm{R}-\mathrm{SiC}_{\mathrm{T} 1500 \mathrm{t} 120}(1292$ a.u. $)>\mathrm{R}-$ $\mathrm{SiC}_{\mathrm{T} 1500 t 60}$ (1097 a.u.) > $\mathrm{R}-\mathrm{SiC}_{\mathrm{T} 1500 t 30}(1044$ a.u.). In other words, the intensity increases with increasing retention time. In addition, there are two typical diffraction peaks at $2 \theta=22^{\circ}$ and $31.5^{\circ}$ in three retention time samples, corresponding to (101) and (102) crystal plane of quartzite, respectively. It is clear from the diffractograms that the diffraction peaks are present at $2 \theta=28.5^{\circ}$, corresponding to (111) crystal plane of cristobalite in the $\mathrm{R}-\mathrm{SiC}_{\mathrm{T} 1500 \mathrm{t} 30}$ and the $\mathrm{R}-\mathrm{SiC}_{\mathrm{T} 1500 \mathrm{t} 60}$. This indicates the existence of crystallization of the $\mathrm{SiO}_{2}$. Shatumbu et al. [23] reported that the yield of $\mathrm{SiC}$ increased with the extension of the retention time. Therefore, prolonging the retention time is beneficial to the formation of $\beta-\mathrm{SiC}$.

\section{Chemical composition}

FT-IR spectra of the $\mathrm{R}-\mathrm{SiC}$ samples prepared at different conditions are displayed in Fig. 3b. The peak at $781 \mathrm{~cm}^{-1}$ is due to the anti-symmetric stretching vibration of the $\mathrm{Si}-\mathrm{C}$ bond, indicating the presence of the $\mathrm{SiC}$ in the samples. The stretching vibration peak of the $\mathrm{Si}-\mathrm{O}-\mathrm{Si}$ bond at $1090 \mathrm{~cm}^{-1}$ indicates that excessive $\mathrm{SiO}_{2}$ is still retained in the $\mathrm{SiC}$ complex ceramics. The transformation ratio of the $\mathrm{Si}-\mathrm{O}-\mathrm{Si}$ bond/ $\mathrm{Si}-\mathrm{C}$ bond as well as the content ratio of the $\mathrm{SiO}_{2} / \mathrm{SiC}$ changes in the trend of $\mathrm{R}-$ $\mathrm{SiC}_{\mathrm{T} 1300 \mathrm{t} 120}(1.06)>\mathrm{R}-\mathrm{SiC}_{\mathrm{T} 1400 \mathrm{t} 120}(1.00)>\mathrm{R}-\mathrm{SiC}_{\mathrm{T} 1500 \mathrm{t} 120}$ (0.94). It indicates that with increasing pyrolysis temperature, the residual $\mathrm{SiO}_{2}$ decreases and the formation of $\mathrm{SiC}$ increases. The stretching vibration peaks at different retention times were also located at $1090 \mathrm{~cm}^{-1}$ and $781 \mathrm{~cm}^{-1}$, respectively, indicating the presence of the $\mathrm{SiC}$ and $\mathrm{SiO}_{2}$ in the samples. The transformation ratio of the $\mathrm{Si}-\mathrm{O}-\mathrm{Si}$ bond/Si-C bond as well as the content ratio of the $\mathrm{SiO}_{2} / \mathrm{SiC}$ bond in the samples showed a trend of $\mathrm{R}-$ $\mathrm{SiC}_{\mathrm{T} 1500 \mathrm{t} 30}(1.00)>\mathrm{R}-\mathrm{SiC}_{\mathrm{T} 1500 \mathrm{t} 60}(0.98)>\mathrm{R}-\mathrm{SiC}_{\mathrm{T} 1500 \mathrm{t} 120}$ (0.94). This means that the amount of the $\mathrm{SiC}$ increases 
with increasing retention time, while unreacted $\mathrm{SiO}_{2}$ decreases. By combining the transmission ratio of the $\mathrm{Si}-\mathrm{C}$ bond/Si-O-Si bond, the ratio of the $\mathrm{R}-\mathrm{SiC}$ samples at different temperatures shows a large range, indicating that the temperature has a more significant influence on the composition of the final $\mathrm{SiC}$ composite ceramics than the retention time. At the same time, there are weak peaks at $1630 \mathrm{~cm}^{-1}$ and $1250 \mathrm{~cm}^{-1}$, which corresponds to the stretching vibration characteristics of the $\mathrm{C}=\mathrm{C}$ bond and $\mathrm{C}-\mathrm{C}$ bond, respectively. This indicates that carbon is left in the $\mathrm{R}-\mathrm{SiC}$ without complete reaction. Hung et al.
[26] also found that there was some unreacted carbon in the sample.

\section{Microstructure and element distribution analysis}

The microstructure and the element distribution of the $\mathrm{SiC}$ multiphase ceramics at different reaction temperatures were investigated by FESEM and EDX and presented in Fig. 4; Fig. a and b are the cross section and longitudinal section of the original rattan, respectively. All prepared samples retain the pore structure of the original rattan. Under low-resolution FESEM images

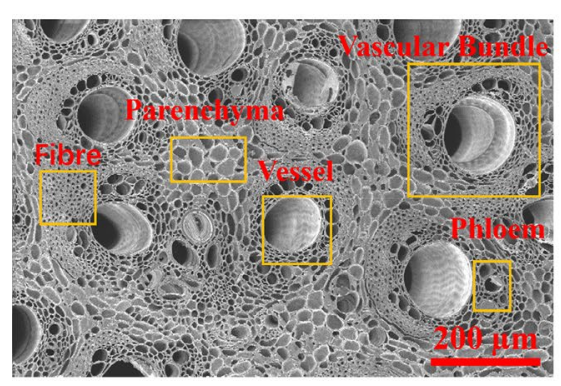

(a)

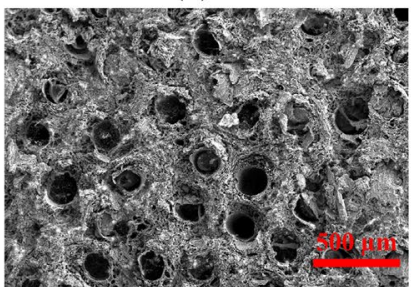

(c)

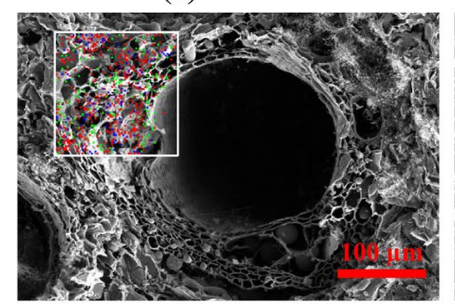

(f)

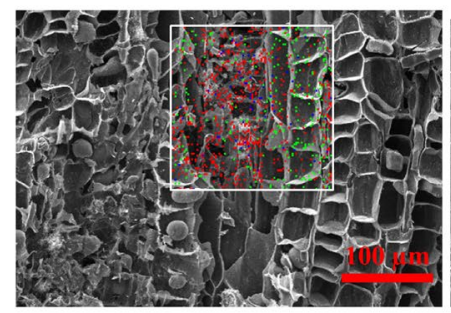

(i)

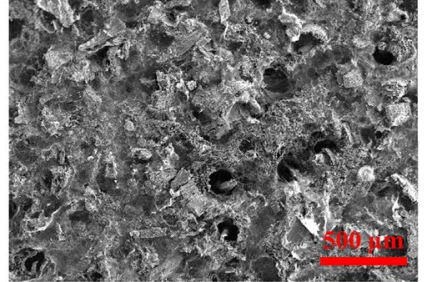

(d)

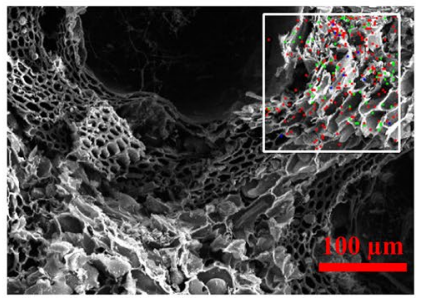

(g)

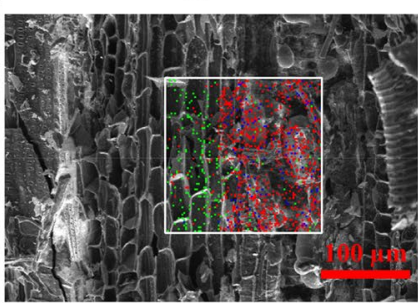

(j)

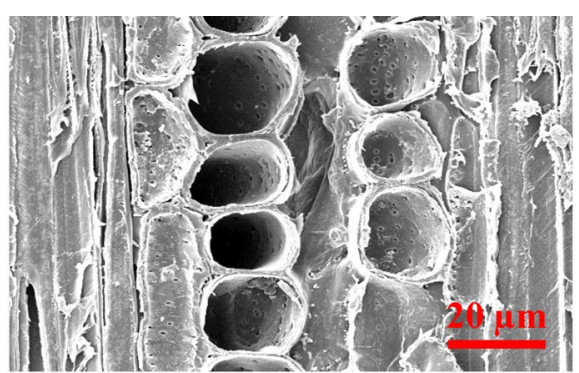

(b)

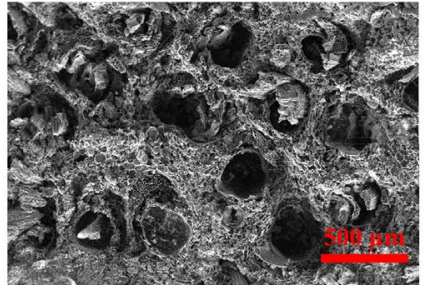

(e)

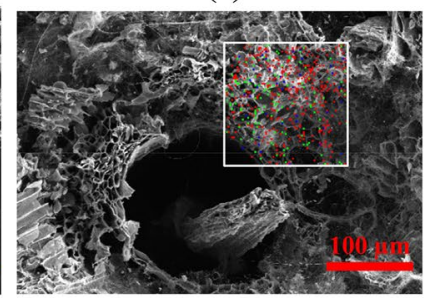

(h)

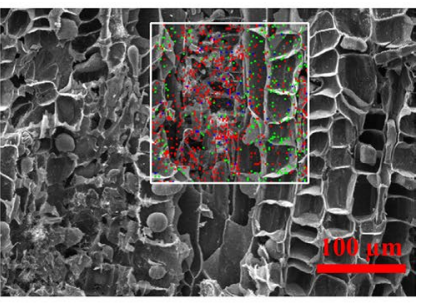

(k)

\section{$\mathrm{C}$}

$\mathrm{Si}$ $\mathrm{O}$

Fig. 4 The FESEM of pristine rattan and the FESEM and the corresponding EDX image of the R-SiC prepared at different temperatures. (Pristine rattan: $\mathbf{a}, \mathbf{b} ; \mathrm{R}-\mathrm{SiC}_{\mathrm{T} 1300 \mathrm{t} 120}: \mathbf{c}$, f and $\mathbf{i} ; \mathrm{R}-\mathrm{SiC}_{\mathrm{T} 1400 \mathrm{t} 120}: \mathbf{d}, \mathbf{g}$ and $\mathbf{j} ; \mathrm{R}-\mathrm{SiC}_{\mathrm{T} 1500 \mathrm{t} 120}: \mathbf{e}, \mathbf{h}$ and $\mathbf{k}$ ) 
(Fig. 4c-e), samples show a vessel-like pore structure with a size of about $170 \mu \mathrm{m}$. This structure is good for the subsequent absorption. Previous research has verified that higher porosity and average pore size correspond to greater averaged absorbing cross sections [21]. With increasing pyrolysis temperature, the amount of filler in the vessel-like pore increases. Under high-resolution FESEM images (Fig. 4f-k), the vascular bundle and the ground parenchymatous tissues of rattan are completely preserved, but some cell rupture or collapse could be visible. With increasing pyrolysis temperature the cell rupture or collapse increases significantly.

On the cross section, the microstructure and element distribution of the vascular bundle structure are shown in Fig. 4f-h. It is composed mainly of $\mathrm{Si}, \mathrm{C}$ and a small amount of $\mathrm{O}$. The presence of $\mathrm{O}$ indicates that there is $\mathrm{SiO}_{2}$ residue in the $\mathrm{R}-\mathrm{SiC}$ samples. The dense distribution of $\mathrm{Si}$ and the sparse presence of $\mathrm{O}$ indicate that the carbothermal reduction of $\mathrm{SiO}_{2}$ occurs in the pyrolysis process, and $\mathrm{SiC}$ is generated. The microstructure and element distribution of the $\mathrm{R}-\mathrm{SiC}$ on the longitudinal section are displayed in Fig. 4i-k. It indicates the structure of the pristine rattan is kept in the $\mathrm{R}-\mathrm{SiC}$, namely vessel, parenchymal cells and fiber cells exist clearly. From the element distribution of EDX, the $\mathrm{R}-\mathrm{SiC}$ on the longitudinal section is also composed of $\mathrm{Si}, \mathrm{C}$ and $\mathrm{O}$, indicating the existence of $\mathrm{SiC}$ and $\mathrm{SiO}_{2}$ in the $\mathrm{R}-\mathrm{SiC}$ samples. On the longitudinal section of the $\mathrm{R}-\mathrm{SiC}$ samples, $\mathrm{Si}$ and $\mathrm{C}$ are distributed regionally with few intersections, indicating that very little $\mathrm{SiC}$ is formed within the $\mathrm{R}-\mathrm{SiC}$, and a certain amount of carbon and $\mathrm{SiO}_{2}$ remains. Although $\mathrm{SiO}_{2}$ sol can enter the interior of rattan piece, the main entry channels are axial cells with large lumen such as vessels. The sol accumulates in the lumen and lacks effective contact with the vessel cell wall. Incomplete reaction during pyrolysis results in the dense distribution of $\mathrm{Si}$ in vessel-like lumen, while little $\mathrm{SiC}$ is produced in the vessel cell walls in the $\mathrm{R}-\mathrm{SiC}$ samples. The amount of the $\mathrm{SiO}_{2}$ sol entering the rattan piece through parenchyma cells with smaller diameter is limited and the distribution is uneven, resulting in the sparse and uneven distribution of $\mathrm{Si}$ and the concentrated distribution of element $\mathrm{C}$ in parenchyma cell of the $\mathrm{R}-\mathrm{SiC}$ samples. This phenomenon indicated that the densification process is related to the open porosity. The rattan porous structure is composed of an interconnected network of solid pillars, and the pore size defines the arrangement of raw materials and the interaction with the surrounding environment [22].

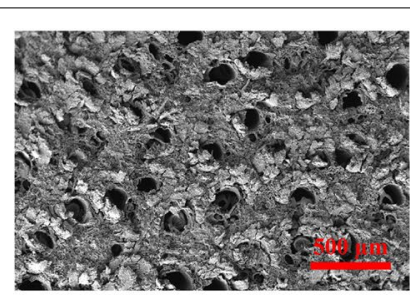

(a)

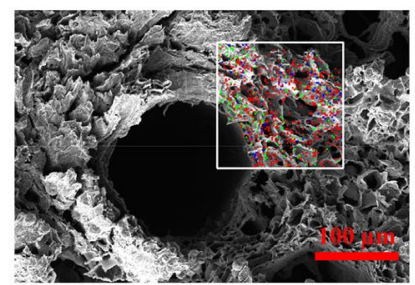

(c)

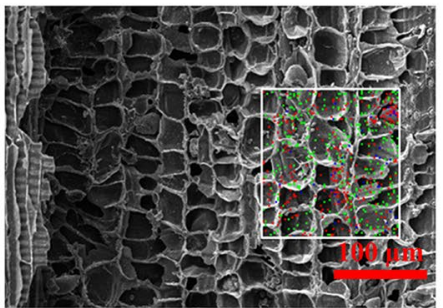

(e)

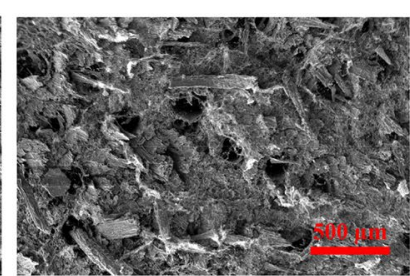

(b)

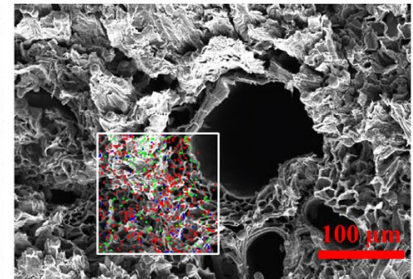

(d)

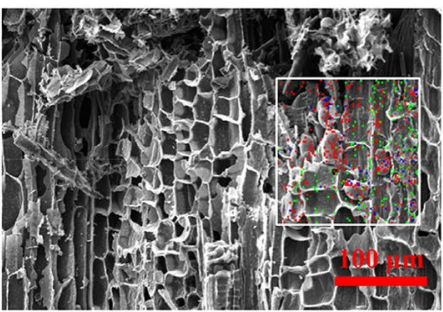

(f)

\section{C}

$\mathrm{Si}$

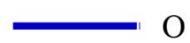

Fig. 5 The FESEM image and the corresponding EDX spectrum of R-SiC at different retention times $\left(\mathrm{R}-\mathrm{SiC}_{T 1500 t 30}: \mathbf{a}, \mathbf{c}\right.$ and $\mathbf{e} ; \mathrm{R}-\mathrm{Si} \mathrm{C}_{T 1500 t 60}: \mathbf{b}, \mathbf{d}$ and f) 
The microstructure and element distribution of the $\mathrm{R}-$ $\mathrm{SiC}$ at different retention times are shown in Fig. 4e, h, $\mathrm{k}$ and Fig. 5. Under low-resolution FESEM images (Fig. 4e and Fig. 5a, b), the cell wall surface is similar to pristine rattan, but it gradually becomes rough or broken, and the filler in the lumen increases with increasing retention time. From the EDX diagram, the element composition of the $\mathrm{R}-\mathrm{SiC}$ samples is $\mathrm{C}, \mathrm{Si}$ and $\mathrm{O}$. It indicates that the $\mathrm{SiC}$ and $\mathrm{SiO}_{2}$ coexist in the $\mathrm{R}-\mathrm{SiC}$ samples. On the cross section (Fig. $4 \mathrm{~h}$ and Fig. 5c, d), the distribution of $\mathrm{C}$ and $\mathrm{Si}$ is relatively dense, while the distribution of $\mathrm{O}$ is sparse. This indicates that a large amount of the $\mathrm{SiC}$ and a small amount of the $\mathrm{SiO}_{2}$ are distributed on the surface of the $\mathrm{R}-\mathrm{SiC}$ samples. On the longitudinal section (Fig. 4k and Fig. $5 \mathrm{e}, \mathrm{f})$, the $\mathrm{Si}$ is densely distributed in the vessel-like lumen, while the $\mathrm{C}$ is concentrated and the $\mathrm{Si}$ is sparse and uneven in the parenchyma cell. It indicates that the $\mathrm{SiO}_{2}$ is largely retained in the large cell lumen such as the vessels, and there is less $\mathrm{SiC}$ formation in the parenchyma cells.

A flocculent structure was found on the surface of the $\mathrm{R}-\mathrm{SiC}$ samples and in the vessel-like lumen (Fig. 6a-b). This flocculent structure is distributed in a disorderly and nondirectional state, while the flocculent structure in the lumen is located in the inner wall of the lumen and the top extends to the outside. The EDX analysis shows that the bamboo-shaped structure is $\mathrm{SiC}$. This means the flocculent structure is actually composed of $\mathrm{SiC}$ whisker disordered arrangement. With increasing reaction temperature and retention time, the output of the $\mathrm{SiC}$ whisker on the $\mathrm{R}-\mathrm{SiC}$ sample surface and in the lumen increases, leading to the lumen to be filled, blocked or even covered. This is similar to the study reported by Zhang et al. [27] and Shatumbu et al. [23].

The weight percentage and atomic number percentage of each element on the cross section and longitudinal section of the $\mathrm{R}-\mathrm{SiC}$ were determined based on the EDX energy spectrum, and the $\mathrm{SiC}$ content in $\mathrm{R}-\mathrm{SiC}$ was calculated. As shown in Table 2, the pattern of variation in $\mathrm{SiC}$ content on the $\mathrm{R}-\mathrm{SiC}$ cross section is consistent with that on the longitudinal section, namely

Table 2 The weight percentage of the $\mathrm{SiC}$ in the $\mathrm{R}-\mathrm{SiC}$ samples

\begin{tabular}{|c|c|c|c|c|}
\hline \multirow[t]{2}{*}{ Sample } & \multirow{2}{*}{$\begin{array}{l}\text { Temperature } \\
\left({ }^{\circ} \mathrm{C}\right)\end{array}$} & \multirow{2}{*}{$\begin{array}{l}\text { time } \\
(\min )\end{array}$} & \multicolumn{2}{|l|}{$\mathrm{SiC}$} \\
\hline & & & Cross section (\%) & $\begin{array}{l}\text { Longitudinal } \\
\text { section (\%) }\end{array}$ \\
\hline 1 & 1300 & 120 & $3.82 \pm 0.02$ & $1.11 \pm 0.01$ \\
\hline 2 & 1400 & 120 & $8.58 \pm 0.11$ & $3.47 \pm 0.04$ \\
\hline 3 & 1500 & 120 & $44.24 \pm 0.44$ & $18.29 \pm 0.18$ \\
\hline 4 & 1500 & 60 & $39.28 \pm 0.29$ & $12.81 \pm 0.01$ \\
\hline 5 & 1500 & 30 & $8.35 \pm 0.15$ & $6.87 \pm 0.12$ \\
\hline
\end{tabular}

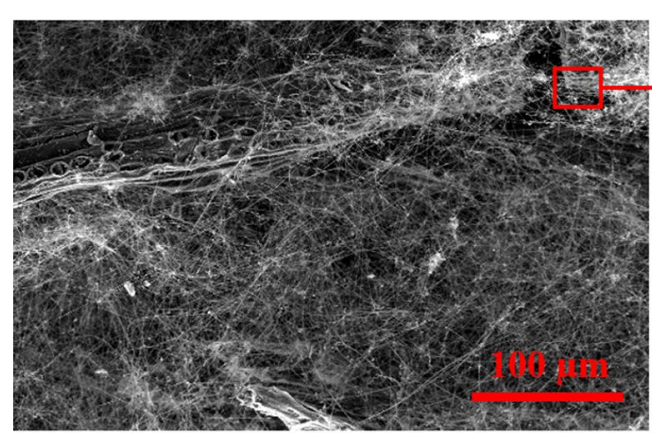

(a)

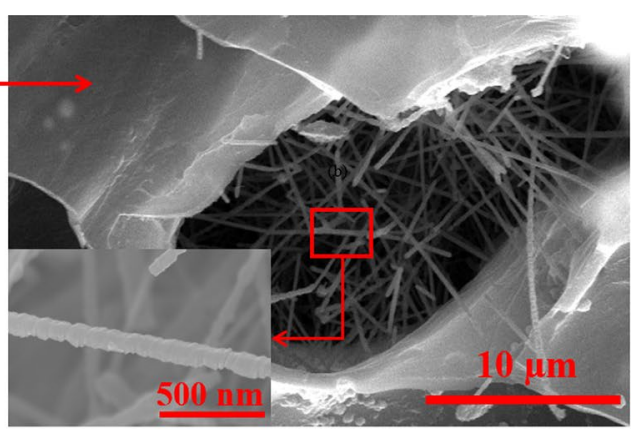

(b)

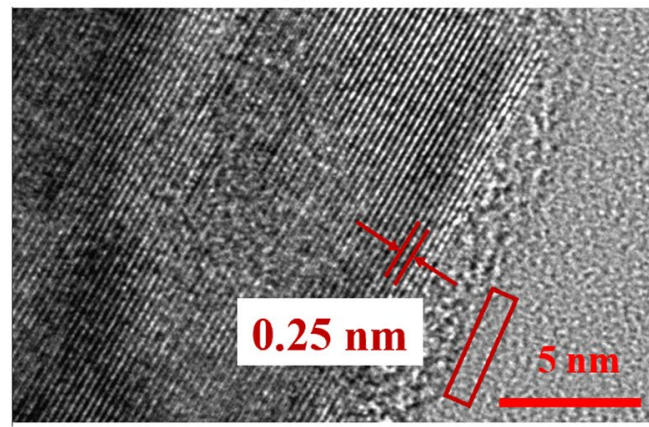

(c)

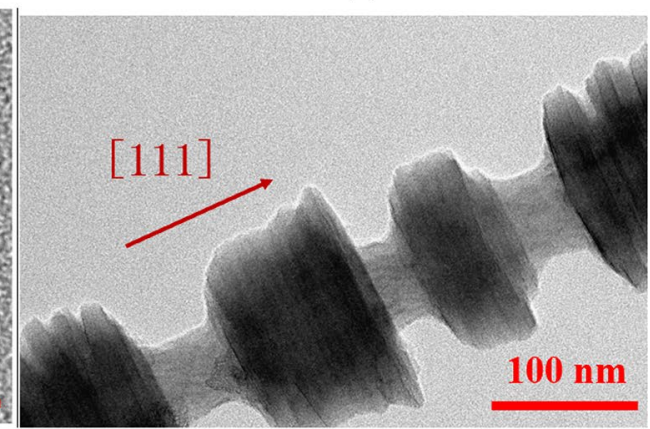

(d)

Fig. $\mathbf{6}$ a and $\mathbf{b}$ FESEM image and the corresponding EDX spectrum of SiC whisker; $\mathbf{c}$ and $\mathbf{d}$ TEM image of the R-SiC 
$\mathrm{R}-\mathrm{SiC}_{\mathrm{T} 1300 \mathrm{t} 120}<\mathrm{R}-\mathrm{SiC}_{\mathrm{T} 1400 \mathrm{t} 120}<\mathrm{R}-\mathrm{SiC}_{\mathrm{T} 1500 \mathrm{t} 120}, \quad \mathrm{R}-$ $\mathrm{SiC}_{\mathrm{T} 1500 t 30}<\mathrm{R}-\mathrm{SiC}_{\mathrm{T} 1500 \mathrm{t} 60}<\mathrm{R}-\mathrm{SiC}_{\mathrm{T} 1500 \mathrm{t} 120}$. This indicates that with increasing pyrolysis temperature and retention time, the amount of the $\mathrm{SiC}$ increases. In addition, the variation e of the $\mathrm{SiC}$ content among the $\mathrm{R}-\mathrm{SiC}_{\mathrm{T} 1300 \mathrm{t} 120}$, the $\mathrm{R}-\mathrm{SiC} \mathrm{T}_{\mathrm{T} 1400 \mathrm{t} 120}$ and the $-\mathrm{SiC}_{\mathrm{T} 1500 \mathrm{t} 120}$ (transverse section: 488.01, longitudinal section: 88.73) is greater than that of the $\mathrm{R}-\mathrm{SiC}_{\mathrm{T} 1500 \mathrm{t} 30}, \mathrm{R}-\mathrm{SiC}_{\mathrm{T} 1500 \mathrm{t} 60}$ and $\mathrm{R}-\mathrm{SiC} \mathrm{T}_{\mathrm{T} 1500 \mathrm{t} 120}$ (transverse section: 378.23, longitudinal section: 32.62 ). This implies that temperature has a more significant influence on the $\mathrm{SiC}$ content in the $\mathrm{R}-\mathrm{SiC}$ samples. Moreover, the distribution of the $\mathrm{SiC}$ on the transverse section is mainly in the form of the $\mathrm{SiC}$ whisker on the rattan skeleton surface or in the lumen, but not in the longitudinal section. In the pyrolysis process, complex carbothermal reduction reactions exist, involving solid-solid reaction, gas-solid reaction and gas-gas reaction [28, 29]. Considering the $\mathrm{SiC}$ whisker forming mechanism of gas-gas phase reaction, it is reasonable to assume that the $\mathrm{R}-\mathrm{SiC}$ mainly conducts solid-solid or solid-gas reaction on the longitudinal section.

Above all, there are two forms of $\mathrm{SiC}$ in the rattanbased $\mathrm{SiC}$ composite ceramics: independent $\mathrm{SiC}$ whisker and $\mathrm{SiC}$ attached to the cell wall. As shown in Fig. 6c and $d$, the interplanar spacing between two adjacent lattice fringes is $0.25 \mathrm{~nm}$, which is consistent with the (111) planes of the $\beta-\mathrm{SiC}$, indicating that the $\mathrm{SiC}$ whiskers grow along the [111] direction due to its lowest nucleation energy on the (111) crystal plane [30]. The other phase of disordered distribution (marked with red rectangle) is the residual rattan carbon that has not been reacted completely and still retains amorphous structure without crystallization under the pyrolysis conditions. This is consistent with the XRD results shown above, and the formed $\mathrm{SiC}$ is bound closely to the residual carbon cell wall. The irregular accumulation and stacking faults during the growth process lead to its bamboo-like morphology, as shown in Fig. 6d. Similar observations were reported by $\mathrm{Wu}$ et al. [31]. They prepared diameter-fluctuating $\mathrm{SiC}$ nanowires with bamboo-like morphology using bamboo-made paper and $\mathrm{Si}-\mathrm{SiO}_{2}$ mixed powders as the raw materials by carbonizing. Zhang et al. [32] proposed a synergistic growth mechanism from the perspective of homogeneous substrate as well as the varying elastic energy to explain the formation of the bamboolike $\mathrm{SiC}$.

Rattan materials are similar to wood and bamboo, and they have a porous structure that renders them useful for realizing different penetration and treatment procedures [33]. The ceramic made from rattan retained the original structural features and unique microstructure as wood and bamboo being raw materials [34, 35]. On the surface of the SiC sample of wood and bamboo and in the vessel-like lumen, there are also flocculent structures composed of $\mathrm{SiC}$ whisker disordered arrangement and distributed in a disorderly and nondirectional state [36, 37]. The high-resolution electron microscopy shows that the $\mathrm{R}-\mathrm{SiC}$ flocculent structure consists of a single bamboo-like structure. Its characteristic shapes such as string-beads-like, bamboo-like and rod-like in the $\mathrm{SiC}$ crystals prepared from wood and bamboo [3841 . But the total porosity of rattan is larger than those of wood or bamboo [42]. It provides a more convenient channel for $\mathrm{SiO}_{2}$ sol impregnation and increases the space contact with $\mathrm{SiO}_{2}$ sol. Compared with wood and bamboo, the effects of $\mathrm{SiO}_{2}$ sol impregnation is more uniform, and $\mathrm{SiC}$ is more fully formed. The natural and special structure of rattan can bring good performance, and it may be more widely used in the future.

\section{Conclusions}

By the sol-gel method, rattan-based $\mathrm{SiC}$ composite ceramics $(\mathrm{R}-\mathrm{SiC})$ were prepared at the different temperatures and retention times in one-step pyrolysis. It is found that both temperature and retention time have a significant influence on the final $\mathrm{R}-\mathrm{SiC}$ products. With increasing reaction temperature and retention time, the carbothermal reduction reaction of $\mathrm{SiO}_{2}$ gel and carbon is increasingly thorough in the pyrolysis process, and the $\mathrm{SiC}$ amount increases. The $\mathrm{SiC}$ mainly exists in the surface and pore of the $\mathrm{R}-\mathrm{SiC}$ in the form of the $\mathrm{SiC}$ whisker. A small amount of the $\mathrm{SiC}$ binds closely to residual carbon in the interior of the $\mathrm{R}-\mathrm{SiC}$.

The pyrolysis parameters studied are able to retain the pore structure of rattan-based $\mathrm{SiC}$ composite ceramics completely, and the specific surface area of the $\mathrm{R}-\mathrm{SiC}$ goes up with increasing temperature and retention time. The $\mathrm{R}-\mathrm{SiC}$ prepared at $1500{ }^{\circ} \mathrm{C}$ and kept for $120 \mathrm{~min}$ has more complete pore structure, lower density $\left(2.35 \mathrm{~g} / \mathrm{cm}^{3}\right)$, higher specific surface area $(43.48$ $\left.\mathrm{m}^{2} / \mathrm{g}\right), \mathrm{SiC}$ yield (44.24\%) and lower $\mathrm{SiO}_{2}$ residue.

\section{Abbreviations}

R-SiC: Rattan-based silicon carbide; SiC: Silicon carbide; CVD: Chemical vapor deposition; PIP: Precursor infiltration pyrolysis; TEOS: Ethyl orthosilicate; EtOH: Anhydrous ethanol; XRD: X-ray diffraction; XRF: X-ray fluorescence; FT-IR: Fourier transform-infrared spectroscopy; FESEM: Field-emission scanning electron microscope; EDX: Energy dispersive X-ray analysis; TEM: Transmission electron microscope; JCPDS: Joint committee on powder diffraction standards.

\section{Acknowledgements \\ The particular support by the Fundamental Research Funds of ICBR (Grant Nos. 1632019019) is acknowledged with thanks.}

\section{Authors' contributions}

LSJ analyzed the data and was a major contributor in writing the manuscript. CHS performed the experiment. SLL supervised and supported the study. LXE was another major contributor in writing the manuscript. ZY participated in 
designing the experiment. MQL and WYH collected the samples. All authors have read and approved the final manuscript.

\section{Funding}

This work was supported by the Fundamental Research Funds of ICBR (Grant Nos. 1632019019)

\section{Availability of data and materials}

The datasets used and analyzed during the current study are available from the corresponding author on reasonable request.

\section{Declarations}

\section{Ethics approval and consent to participate}

Not applicable.

\section{Consent for publication}

The authors declared that they agreed to publish.

\section{Competing interests}

The authors declare that they have no competing interests.

\section{Author details}

${ }^{1}$ Key Lab of Bamboo and Rattan Science and Technology, International Centre for Bamboo and Rattan, Beijing 100102, China. ${ }^{2}$ School of Forestry \& Landscape Architrcture, Anhui Agricultural University, Hefei 230036, China. ${ }^{3}$ Beijing Research Institute of Synthetic Crystals Co. Ltd, Beijing 100018, China.

Received: 10 June 2021 Accepted: 1 October 2021

Published online: 15 October 2021

\section{References}

1. Wang H, Bi Y, Zhou N (2016) Preparation and strength of SiC refractories with in situ $\beta$-SiC whiskers as bonding phase. Ceram Int 42:727-733

2. He R, Ding G, Zhang K (2019) Fabrication of SiC ceramic architectures using stereolithography combined with precursor infiltration and pyrolysis. Ceram Int 45(11):14006-14014

3. Zhou X, Wang N, Lai H (1999) $\beta$-SiC nanorods synthesized by hot filament chemical vapor deposition. Appl Phys Lett 74(26):3942-3944

4. Kim BG, Yoon JY, Yoo CH (2015) Condensation of vapor species at the outlets in high temperature chemical vapor deposition using tetramethylsilane as a precursor for SiC bulk growth. CrystEngComm 17(16):3148-3152

5. Zollfrank C, Kladny R, Sieber H (2004) Biomorphous SiOC/C-ceramic composites from chemically modified wood templates. J Eur Ceram Soc 24(2):479-487

6. Chen L, Yang X, Su Z (2018) Fabrication and performance of microdiamond modified C/SiC composites via precursor impregnation and pyrolysis process. Ceram Int 44(8):9601-9608

7. Xiang Y, Li W, Wang S (2012) Oxidation behavior of oxidation protective coatings for PIP-C/SiC composites at $1500{ }^{\circ} \mathrm{C}$. Ceram Int 38:9-13

8. Liu L, Li H, Feng W (2013) Effect of surface ablation products on the ablation resistance of C/C-SiC composites under oxyacetylene torch. Corros Sci 67:60-66

9. Chollon $\mathrm{G}$ (2021) The high temperature reaction of ammonia with carbon and SiC-C ceramics. J Eur Ceram Soc 41(1):136-147

10. Zampieri A, Sieber H, Selvam T (2005) Biomorphic cellular SiC/zeolite ceramic composites: from rattan palm to bioinspired structured monoliths for catalysis and sorption. Adv Mater 17(3):344-349

11. Zeni TL, Rambo CR, Magalhães WL (2013) Control of porosity and permeability of wood by fungi action for biotemplating of SiC. J Wood Chem Technol 33(1):33-43

12. Riikonen J, Rantanen J, Thapa R (2021) Rapid synthesis of nanostructured porous silicon carbide from biogenic silica. J Am Ceram Soc 104(2):766-775

13. Yang SM, Xiang EL, Shang LL (2020) Comparison of physical and mechanical properties of four rattan species grown in China. J Wood Sci. https://doi.org/10.1186/s10086-020-1850-0
14. Shang LL, Jiang ZH, Liu XE (2016) Effect of modification with methyl methacrylate on the mechanical properties of plectocomia kerrana rattan. Bioresources 11(1):2071-2082

15. Yudodibroto H. (1985) Anatomy, strength properties and the utilization of some Indonesian rattans. Procedings of the rattan seminar, 2-4 Oct 1984, Kuala Lumpur, Malaysia the Rattan Information Centre, pp. 117-122

16. Liu XE, Tian GL, Shang LL (2014) Compression properties of vascular bundles and parenchyma of rattan (Plectocomia assamica Griff). Holzforschung 68(8):927-932

17. Abasolo WP, Yoshida M (2003) Thermal softening of rattan canes: influence of the hemi- cellulose-lignin matrix. World Bamboo Rattan 1(4):317-331

18. Maity A, Das H, Kalita D (2014) Studies on formation and siliconization of carbon template of coir fibreboard precursor to SiC ceramics. J Eur Ceram Soc 34(15):3499-3511

19. Gryshkov O, Klyui NI, Temchenko VP (2016) Porous biomorphic silicon carbide ceramics coated with hydroxyapatite as prospective materials for bone implants. Mater Sci Eng C 68:143-152

20. Cui HS, Zheng Y, Ma JF (2017) Effect of different silicon sources on rattanbased silicon carbide ceramic prepared by one-step pyrolysis. J Wood Sci 63(1):95-103

21. Albano M, Delfini A, Pastore R (2016) A new technology for production of high thickness carbon/carbon composites for launchers application. Acta Astronaut 128:277-285

22. Pastore R, Delfini A, Micheli D (2019) Carbon foam electromagnetic mmwave absorption in reverberation chamber. Carbon 144:63-71

23. Shatumbu T, Alweendo A, Oluwagbenga T (2019) Synthesis, optimization and characterization of silicon carbide SiC from rice husk. 2nd International conference on sustainable materials processing and manufacturing. Procedia Manuf 35:962-967

24. Gu J, Lee SH, Lee HS (2021) Fast pyrolysis of a SiC-based polymer precursor using a spark plasma sintering apparatus-effects of heating methods and pyrolysis atmosphere. J Eur Ceram Soc 41(4):2297-2305

25. Kuang JL, Xiao T, Hou XJ (2019) Microwave synthesis of worm-like SiC nanowires for thin electromagnetic wave absorbing materials. Ceram Int 45:11660-11667

26. Hung KC, Wu TL, Xu TW (2019) Preparation of biomorphic porous SiC ceramics from bamboo by combining sol-gel impregnation and carbothermal reduction. Polymers 11(9):1442

27. Zhang NC, Yu AX, Liang AH (2013) Preparation of SiC whisker and application in reinforce of polystyrene resin composite materials. J Appl Polym Sci 130(1):579-586

28. Sujirote K, Leangsuwan P (2003) Silicon carbide formation from pretreated rice husks. J Mater Sci 38(23):4739-4744

29. Herzog A, Klingner R, Vogt U (2004) Wood-derived porous SiC ceramics by sol infiltration and carbothermal reduction. J Am Ceram Soc 87(5):784-793

30. Zhang XN, Chen YQ, Xie ZP (2010) Shape and doping enhanced field emission properties of quasialigned 3C-SiC nanowires. J Phys Chem C 114:8251-8255

31. Wu ZH, Zheng HK, Zhang GL (2020) Synthesis of diameter-fluctuating silicon carbide nanowires for excellent microwave absorption. Mater Chem Phys 244:122648-122671

32. Zhang M, Zhao J, Li ZJ (2016) Bamboo-like 3C-SiC nanowires with periodical fluctuating diameter: homogeneous synthesis, synergistic growth mechanism, and their luminescence properties. J Solid State Chem 243:247-252

33. Liu HR, Jiang ZH, Fei BH (2015) Tensile behavior and fracture mechanism of moso bamboo (Phyllostachys pubescens). Holzforschung 69(1):47-52

34. Huang TX, Li Z, Huang YQ (2020) Microstructure and wear properties of $\mathrm{SiC}$ wood ceramics reinforced high-chromium cast iron. Ceram Int 46(3):2592-2601

35. Guo XZ, Zhu L, Li WY (2013) Preparation of SiC powders by carbothermal reduction with bamboo charcoal as renewable carbon source. J Adv Ceram 2(2):128-134

36. Ershov AE, Klassen NV (2015) Control of functional characteristics of biomorphous carbon matrices, SiC-Si-C composites, and SiC-C ceramics by prepressing wood. Inorg Mater 6(1):79-90

37. Zhu JT, Jia JC, Kwong FL (2013) Synthesis of 6H-SiC nanowires on bamboo leaves by carbothermal method. Diam Relat Mater 33:5-11 
38. Chiew YL, Cheong KY (2011) A review on the synthesis of SiC from plantbased biomasses. Mater Sci Eng B Adv 176(13):951-964

39. Li Z, Shi TJ, Tan DX (2013) Conversion of a wood flour-SiO ${ }_{2}$-phenolic composite to a porous SiC ceramic containing SiC whiskers. J Serb Chem Soc 78(8):1213-1223

40. Yukhymchuk VO, Kiselov VS, Valakh MY (2016) Biomorphous SiC ceramics prepared from cork oak as precursor. J Phys Chem Solids 91:145-151

41. LiensdorfT, Schoch R, Lang M (2020) Silicon infiltrated silicon carbide from extruded thermoplastic wood polymer composites. Int J Appl Ceram Tec 17(1):3-10
42. Lin YJ, Lo XW (2011) Fabrication of SiC and SiC/aluminum-silicon composites from rattan charcoal. Key Eng Mater 479:119-123

\section{Publisher's Note}

Springer Nature remains neutral with regard to jurisdictional claims in published maps and institutional affiliations.

\section{Submit your manuscript to a SpringerOpen ${ }^{\odot}$ journal and benefit from:}

- Convenient online submission

- Rigorous peer review

- Open access: articles freely available online

- High visibility within the field

- Retaining the copyright to your article

Submit your next manuscript at $\boldsymbol{\nabla}$ springeropen.com 